\title{
Request Strategy Development in Iranian Study Abroaders
}

\author{
Hassan Rasouli Khorshidi (Corresponding author) \\ Department of studies in Linguistics, KIKS \\ University of Mysore, Mysore \\ Manasagangotri, Mysore-06 \\ Tel: +91-9739-766-137 E-mail: rasouli222@gmail.com \\ Rangasawmy Subbakrishna \\ Professor-cum-Deputy Director, \\ Central Institute of Indian Languages (CIIL) \\ Masagangotri, Mysore-570006 \\ Tel: +91-821-234-51510 E-mail: rsubbakrishna@gmail.com
}

Received: 15-07-2013

doi:10.7575/aiac.ijalel.v.2n.6p.129
Accepted: 21-08-2013

Published: 01-11-2013

\begin{abstract}
This longitudinal study empirically investigated the development of request strategies in Iranian study abroaders. More specifically, this study aimed at exploring if length of stay in L2 context impacts learners' number and type of strategies. To this end, 72 students who registered in a six month study abroad program and 60 native speakers from U.S. Britain, Australia, and Canada agreed to participate in the present study. The learners in this investigation were tested at three phases. In the first phase, the study abroad (SA) group was given a Discourse Completion Task (DCT) at the beginning of the program as a pre-test. Three months later the same test was administered to the learners as post-test 1 and subsequently at the end of the program once again the test was given to the learners as post-test 2 in order to measure their achievement after three and six months sojourn. The native speakers were also asked to fill the DCT in order to compare the learners' responses to the native speakers'. Finally, through comparing the learners' performances in pre-test and post-tests with each other and with the native speakers', it was found out that first, majority of learners and native speakers used conventionally indirect strategies in their request utterances, second, the number of strategies used by the students steadily increased over time from pre-test to the first and second post-test and third, the type of request strategies used by learners changed to be native like at the end of their sojourn.
\end{abstract}

Keywords: interlanguage pragmatics, pragmatic competence, request strategies, speech acts, study abroad

\section{Introduction}

Long time ago, linguists and language philosophers recognized that language is not merely used to describe things and events, but it is also used to do certain things such as requesting, apologizing, complaining, praising, etc. Golato and Golato (2013) describe speech acts as "the acts a speaker performs when uttering a sentence under normal circumstances" (p. 5332). Among the list of speech acts, request is the most frequent one and is mostly used to start conversations. A request is an illocutionary act through which a speaker asks the hearer to perform an act for the speaker. In this speech act, the requester asks the requestee to carry out something. Because of the impositive nature of a request and as the speaker imposes the interlocutor to perform an act for his or her own benefit, it can be facethreatening. Whenever a request is asked, because the requester is showing power by requesting, the requestee's negative face (i.e. the wish to be unimpeded) is threatened. If the hearer refuses to carry out the required act, the speaker is eminent to lose face.

Requests are needed to be studied more because of their high frequency in everyday speech act. Moreover, most of the time communications do start with a request. Skills in requesting are required to make one's request work in a desired way in a specific situation.

\section{Request Categories and Strategies Classification}

Regarding the nature of directness in request speech act, requests are generally classified into three categories. Here, the term directness, as Blum-Kulka, House and Kasper (1989a) assert, refers to "the degree to which the speakers' illocutionary intent is apparent from the locution" (p. 278). In this study, the directness category classification for request is based on Blum-Kulka (1989), House and Kasper (1989a), and Trosborg (1995). This classification is 
organized from the most to the least direct ones namely direct requests, conventionally indirect requests and nonconventionally indirect requests. This classification with related strategies in each category has been presented below.

- Direct requests: imperatives, performatives (unhedged, hedged), want statements, and locution derivables.

- Conventionally indirect requests: suggestory formula, temporal availability, prediction, permission, willingness, and ability.

- Non-conventionally indirect requests: hints (strong, mild).

\subsection{Direct Requests}

In direct requests, the speakers' intent is clear and straightforward, therefore the interlocutor can easily identify and decipher what the speaker means by that request. Each strategy in this category is shortly explained below:

Imperatives: The most direct forms of requests are Imperatives. In essence, imperatives are so intention clearing that misunderstanding is far to happen. If someone says, "open the door, please", the interlocutor easily understands that a door should be opened and no other meanings can be inferred. Imperatives can be softened by using downtoners or politeness markers 'please' which reduce the illocutionary force of a request. Without request softeners, imperatives are regarded as impolite outside formal contexts as in military in which they are commonly used.

Performatives: Based on both Cross-Cultural Study of Speech Act Realization Patterns, CCSARP's (Blum-Kulka et al. (1989b) and Trosborg's (1995) coding scheme, the second direct form of request strategies are performatives. In this type of direct request, a performative verb like ask, command or request is used to declare the intent of the request. Performatives are subcategorized as unhedged and hedged performatives. "Unhedged performatives explicitly state the illocutionary force of the request by including a performative verb" (Schauer, 2009, p. 86), for example, 'I ask you to tell me where $I$...'. Like imperatives, unhedged performatives are not regarded as polite requests outside formal contexts either. Therefore, the same as imperatives, unhedged performatives can be mitigated by downgraders such as 'could' in order to reduce their imposition. Hedged performatives on the other hand, also include a performative verb but their illocutionary force is mitigated by using a verb immediately before the performative verb, for example, ' $I$ would like to ask you if you could do me a favor', 'I want to ask you where I ...' (Schauer, 2009, p. 86).

Locution derivables: The third kind of the most direct strategies in this category is locution derivables. Locution derivable requests are those that in which "the illocutionary point is directly derivable from the semantic meaning of the locution" (Blum-Kulka et al., 1989b, p. 279). This strategy seems to be mostly used for asking about the location of something. Examples of this strategy in this research from the native speakers were 'Hey John, which way is the Portland Building?' or 'Do you know where the Portland building is?' or 'Hey Kumar! Where is the Portland building?'.

Want statements: Among the strategies in direct request category, want statements are regarded as the least direct ones. The same as other direct strategies, the intent can easily be inferred by the interlocutor because it is expressed explicitly. Similar to imperatives and performatives, want statements are also considered as rather impolite. However, if they are softened by internal and external modifiers (e.g., downtoners 'maybe', politeness marker 'please', past tense 'could', etc.) they will be regarded as appropriate and polite. For example, 'I would like to borrow your book'. This strategy is categorized differently by different researchers. For example, in the CCSARP Blum-Kulka et al. (1989a) classified it as a direct but Trosborg (1995) named it as a conventionally indirect strategy.

\subsection{Conventionally Indirect Requests}

As a request is impositive by nature and the speaker imposes the interlocutor to carry out a certain task for his or her own benefit and because of the fact that when a request is asked the requester is showing power, the requestee's negative face is possible to be threatened. Therefore, some linguistic and pragmatic techniques are required to create a positive atmosphere when asking a request. Requests in this category are made less transparent by using conventionalized linguistic elements which soften the illocutionary force of the request and lessen the impact of the imposition on the interlocutor. According to Trosborg (1995) and Warga (2004) conventionally indirect requests are comprised of suggestory formula, availability, prediction, permission, willingness and ability.

Suggestory formula: In this kind of request strategy, the illocutionary intent of the utterance is expressed in the form of a suggestion. Examples of this category in my data produced by the native speakers were, 'please reschedule it for tomorrow' or 'please meet tomorrow instead'

Availability: In this strategy, the speaker provides a possible reason or an excuse (e.g., lack of time) to reject the desired act by the interlocutor in order to show that there is no imposition or the speakers makes an attempt to soften the illocutionary force of the request. According to Leech (1983) availability strategy is classified as more polite because it increases the degree of interlocutor's optionality. Examples of this type in this study are: 'Excuse me, I know you are busy but do you have time to complete a questionnaire for me?', 'I'm sorry professor, I realize you are very busy, but is it possible to give me some time to complete this questionnaire?'.

Prediction: In prediction, the speaker decides to make oneself less involved by making an impersonal request. In this strategy, the speaker seeks to perceive if it is possible for the interlocutor to do a certain act in near future. In this strategy, the impact of the illocutionary force is mitigated by impersonal wording of a request (Schauer, 2009). For instance, in the example, is it possible that ...' the illocutionary force is downgraded, therefore this kind of request is 
considered as a very polite one (Van Mulken, 1996; Warga, 2004). Therefore, Schauer (2009) indicates that "this kind of request is mostly used by lower status interlocutors toward higher status interlocutors, as their content signals that the hearer is in a position to predict probabilities" (p. 88). For example, in the present research the prediction requests produced by native speakers and language learners are 'Is there any chance to tell me the way to ...?' or 'I wonder if you could possibly bring some articles that may be helpful to me?'.

Permission: Conventionally indirect strategy permission is employed to draw the hearer's attention. This request is in the form of question which is employed for permission. In this kind of request strategy, the speaker tries to soften the utterance and likes the interlocutors think that they have the power to give permission. Examples of elicited data in this research study are: 'Excuse me! May I get through, please?' or 'Could you tell me which way it is to the Trent building?'. Here, in the former example, this request even can be further softened by employing downgrading devices such as the politeness maker 'please'.

Willingness: The same as availability, in willingness also the speaker provides the interlocutor with an option whether or not to carry out the desired act. In this way the speaker indicates that there is no obligation on the hearer's part to perform the requested act. Therefore, the illocutionary force is softened by providing willingness on the hearer's part because the interlocutor feels free to perform the desired act. Willingness strategies mostly employ the expression 'Would you mind verb+ing'. According to Trosborg's (1995) coding scheme, willingness may also be embedded in expressions of hope, appreciation, and so on. For instance, 'It would be great if you could bring them in tomorrow for me.'

Ability: The last but the most important conventional indirect strategy is ability. This kind of request addresses the requestee's mental or physical capability to carry out the desired act in the request utterance. Bublitz (2001) believes that among the conventionally indirect strategies, ability is often considered as the standardized and common form of request. This strategy mostly makes use of the modal 'can' or 'could'. In our data, there were examples such as 'Hey Karen, can you open the window?', 'Could you please fill in the questionnaire for me?' or 'Can I squeeze past you guys?'.

\subsection{Non-conventionally Indirect Requests}

Non-conventionally indirect requests are regarded as the least direct form of request utterances. Basically, nonconventionally indirect requests were divided into two subcategories namely mild and strong hints. But in this study following (Achiba, 2003; Warga, 2004; Weizmann, 1993) all hints are combined into one category. An example found in our data was 'excuse me Guys' (when the speaker asked friends to step aside in scenario14). Hints are regarded as the least transparent and clear form of requests therefore the same as hedged performative or locution derivable request utterances, the interlocutor needs more time to decode what exactly the desired act by the speakers is. Like availability, request utterances in the form of hints provide the interlocutor with an optionality to perform the desired act. Therefore, this strategy is also considered as low in illocutionary force. Because of the high level of indirectness in hints, there is a risk that the hearer may not understand the request. Schauer (2009) comments that unlike direct and conventionally indirect requests, "hints are also more likely to be misinterpreted or not recognized as a request" (p. 88).

\section{Research question}

- Does the study abroad make L2 learners more native like in their use of request strategies regarding the number \& type of strategies?

\section{Methodology}

In the present study, the researchers tested a group of Iranian English language learners who registered to study English in Indian language schools as a study abroad program. The researchers investigated to see if length of stay affects learner's pragmatic competence in the employment of request strategies, and if it does, what the changes are in the learners' use of these strategies.

\subsection{Participants}

The sample selection in this research study is that of available samples. The samples are already placed at the intermediate level through a placement test and an interview by the language institutes. A group of 72 Iranian English language learners that have already registered at a six month study abroad program at English language institutes in Mysore, India were chosen as participants. For the native speaker group, thanks to Mysore city for being a yoga training destination, 60 native speakers from U.S, Britain, Australia, and Canada filled the questionnaire. Fortunately, the strategies studied in this research helped the researchers a lot to convince the native speakers to fill the questionnaire. The native speakers were spotted and were asked to fill the questionnaire and fortunately most of them kindly collaborated. After their yoga training classes, they kindly gave the researchers some time to fill the Discourse Completion Task (DCT).

\subsection{Instruments}

In the present study the researchers used an open questionnaire called Discourse Completion Task (DCT) (appendix A) on request developed by Schauer (2009). This DCT was skillfully organized by the developer in a way that it includes scenarios with equal and higher status and at the same time with low and high imposition features. 
Table 1. Categorization of the request scenarios according to the two variables 'status' and 'imposition'
Low imposition
High imposition

\begin{tabular}{lll}
\hline Equal & Scenario 7 'speak louder' & Scenario 3 'fill out questionnaire' \\
status & Scenario 9 'open window & Scenario 6 'postpone sth.' \\
& Scenario 12 'give directions' & Scenario 10 'borrow sth.' \\
& Scenario 14 'move away from door' & Scenario 15 'arrange meeting' \\
& & \\
Higher & Scenario 1 'open window' & Scenario 4 'borrow sth.' \\
status & Scenario 2 'give directions' & Scenario 8 'arrange meeting' \\
& Scenario 5 'move away from door' & Scenario 11 'fill out questionnaire' \\
& Scenario 16 'speak louder' & Scenario 13 'postpone sth. \\
\hline
\end{tabular}

In this table, the scenarios are arranged into four blocks. Each block contains requests with equal or higher status categorized as low imposition and high imposition requests. The eight equal status scenarios and the eight higher status scenarios are based on the same request situations. In equal status situations, the speaker and the interlocutor belong to the same social level while in higher status situations the speaker is asking a person who is in higher social class to do something. As a matter of fact, this questionnaire is comprised of eight scenarios but each scenario is presented in two categories of equal and higher status in order to get contextually different situations. Furthermore, another categorization is also employed for each level namely, low and high imposition. The difference between these two is that in high imposition, the speaker has to first pave the way for the request. For example, in scenarios 6 (equal status) and 13 (higher status) the speaker first has to cancel an already arranged meeting and then postpone it to another day. However, in low imposition scenarios a prerequisite action is not needed. For example, in scenarios 7 (equal status) and 16 (higher status) you ask a friend or a professor to speak louder. In low imposition category the speaker puts a low imposition on the hearer (e.g., asking a friend to open a window).

\subsection{Procedure}

The required data were elicited through manipulating the above mentioned instrument step by step as follows:

Phase 1: At the beginning of the program, the DCT was given to the students to estimate their basic pragmatic competence on request strategies (pre-test).

Phase 2: After three months of instruction by the institute, the same test was administered to the students to measure their possible improvement (post-test 1).

Phase 3: At the end of the six month program, the request questionnaire was given to the students one more time. This time the aim was to measure the total gain of the SA learners after six months studying abroad (post-test 2).

\section{Final step}

To find out the number and type of strategies the learners and native speakers used, professor Subbakrishna from Central Institute of Indian Languages (CIIL), University of Mysore and two native speaker English language teachers helped the researchers to find out the strategies the participants employed in each scenario and also scored the participants' responses to the scenarios.

\section{Results and Discussion}

In this study, the pretest was administered to elicit the participants' number of strategies they already knew at the beginning of their study abroad. Post-tests 1 and 2 were administered to measure the number of request strategy types they achieved through study abroad program within 3 and 6 months sojourn. Figure 1 below illustrates the number of strategies employed by the SA learners in pre-test (at the beginning of the program), post-test 1 (after three months) and post-test 2 (after six months). The average number of different strategy types employed by the SA learners in pre-test was 3.15 , post-test 1 was 4.98 , and post-test 2 was 6.34 while the average for the native speakers was 8.45 . Table 2 and figure 1 below depict the SA and native speakers' performance on the request DCT.

\subsection{Number of strategies}

Table 2. Average number of strategy types employed by SA group and native speakers

\begin{tabular}{lc}
\hline & Average number of strategies \\
\hline SA pre-test & 3.15 \\
\hline SA post-test 1 & 4.98 \\
\hline SA post-test 2 & 6.34 \\
\hline Native speakers & 8.45 \\
\hline
\end{tabular}




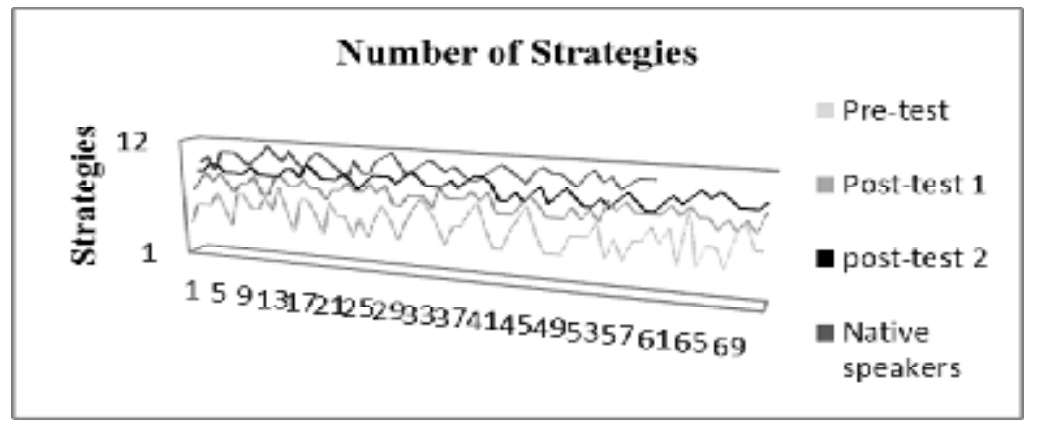

Figure 1. Number of strategies employed by the SA learners and native speakers

A simple comparison of the average number of strategies shows that the SA learners achieved some gains in post-test 1 after three months and their strategy repertoire also increased in number after six months and they steadily moved toward being native like. Consequently, it can be claimed that through the study abroad the learners became more native like in using request strategies. This finding is in line with the findings by Schauer (2009) with her German learners.

\subsection{Strategies development in SA learners}

As it was mentioned before, the coding scheme in this research for the request strategies is based on Blum-Kulka (1989), Blum-Kulka, House and Kasper (1989a), Trosborg (1995) and Van Mulken (1996). Three major categories of request strategies were under investigation in this research study namely, direct requests (imperatives, performatives, locution derivables, and want statements), conventionally indirect requests (suggestory formula, temporal availability, prediction, permission, willingness, and ability), and non-conventionally indirect requests (hints).

Table 3 below indicates that considering the direct locution derivable strategy as an exception, a great number of SA learners and native speakers used more conventionally indirect request category than direct strategies. This represents the popularity, usability, and user-friendly characteristic of conventionally indirect category in request speech act. This is well illustrated separately in figure 2 below.

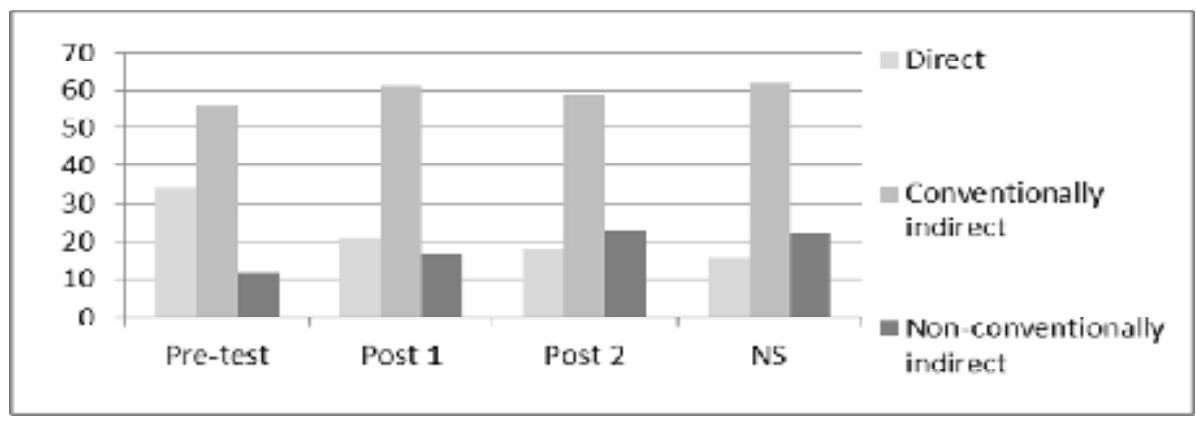

Figure 2. Comparison of request categories used by SA and native speakers

\subsection{Direct request strategies}

In the following, the SA learners' use of direct strategies are discussed by comparing their performance in the pre-test, post-test 1 and post-test 2 along with a comparison with native speakers' performance as well.

Table 3. Percentage of the strategies used in each test by SA learners and native speakers

\begin{tabular}{llcccc}
\hline $\begin{array}{l}\text { Request } \\
\text { categories }\end{array}$ & $\begin{array}{l}\text { Request } \\
\text { strategies }\end{array}$ & $\begin{array}{c}\text { Pre-test } \\
\%\end{array}$ & $\begin{array}{c}\text { Post-test1 } \\
\%\end{array}$ & $\begin{array}{c}\text { Post-test2 } \\
\%\end{array}$ & $\begin{array}{c}\text { NSs } \\
\%\end{array}$ \\
\hline \multirow{2}{*}{$\begin{array}{l}\text { Direct } \\
\text { strategies }\end{array}$} & Imperatives & 14 & 8.5 & 5 & 2 \\
& Performatives & 13 & 8.5 & 5 & 2 \\
& Locution derivables & 3 & 6 & 7 & 4 \\
Want statements & 5 & 3.3 & 2.25 & 1 \\
$\begin{array}{l}\text { Conventionally } \\
\text { indirect strategies }\end{array}$ & Suggestory formulas & 0 & 0.6 & 1 & 0.5 \\
& Temporal availability & 3 & 6.5 & 9 & 7 \\
& $\begin{array}{l}\text { Prediction } \\
\text { Permission }\end{array}$ & 6 & 10 & 12 & 14 \\
& Willingness & 10 & 8.6 & 11 & 14 \\
\multirow{2}{*}{$\begin{array}{l}\text { Non-conventionally } \\
\text { indirect requests }\end{array}$} & Ability & 38 & 31 & 26 & 20 \\
& Hints & & & & \\
\hline
\end{tabular}




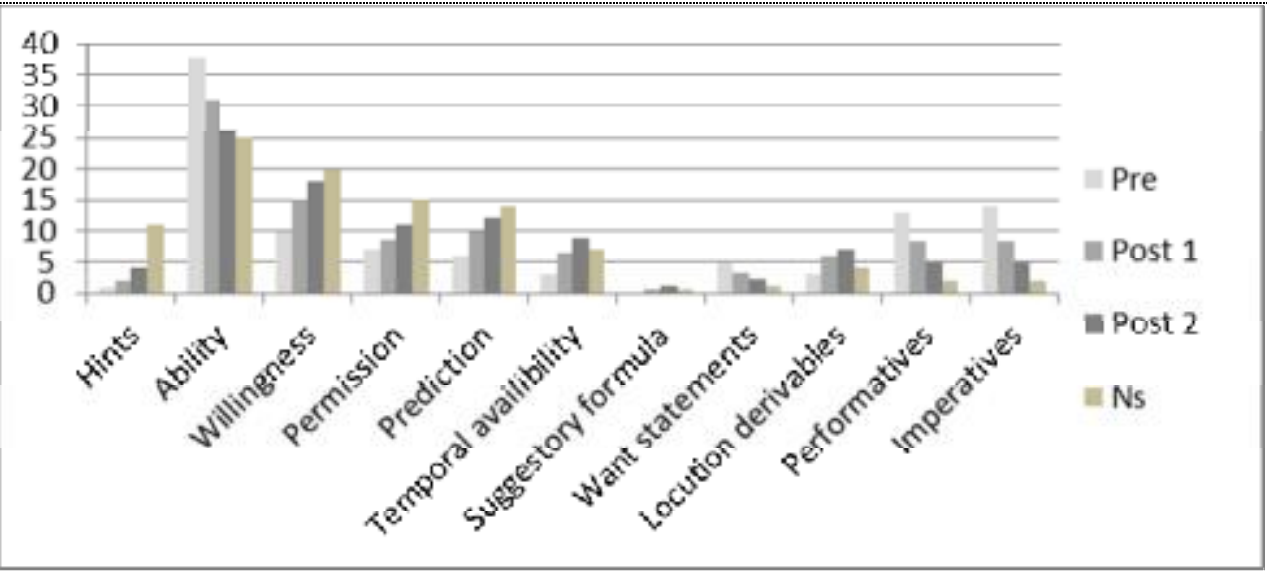

Figure 3. Percentage of the strategies used in each test by learners and native speakers

Table 3 and figure 3 are actually very illustrative. Based on the table and figure, the use of all the strategies by both learners and native speakers are discussed below.

As it can be seen in this illustrative figure 3 above, imperatives were rarely employed by SA sojourners and native speakers. Actually, imperatives were used only in scenarios with equal status with low imposition (e.g., scenarios 7, 9, $12,14)$. In the pre-test some learners used imperative strategies, but in post 1 and 2 most of them stopped using imperatives and resorted to other conventionally indirect strategies. Only 2 percent of the native speakers employed imperatives in scenarios 7,9 and 14. The results suggest that through study abroad the learners found out that imperatives are not favored by native speakers; therefore they substituted it for other indirect strategies that were used by native speakers such as ability, willingness, or hedged performatives. This change in the strategy use which made the SA learners closer to the native speakers can be regarded as evidence of the positive impact of pragmatic development in study abroad context. It is worth to mention that the imperatives employed by the native speakers and most SA learners in the post-tests were equipped with linguistic downtoning devices such as politeness marker 'please'. For example, 'open the window please' or 'please let me through'. Downtoners are used along with imperatives to soften or mitigate the illocutionary force of the request (Labov \& Fanshel, 1997).

Another impact of study abroad context is indicative in the SA learners' performance in their alteration in the use of performatives. Some learners stopped to employ unhedged performatives in the post-tests and shifted to using conventionally indirect strategies. Results show that in the pre-test a number of learners (12\%) used unhedged performatives in high imposition requests which gradually disappeared in the subsequent post-tests. This strategy was rarely used by native speakers and SA learners in post-test 2. The learners who employed unhedged performatives in pre-test, stopped using this strategy and shifted to either a conventionally indirect strategy or a hedged performative which is softer in illocutionary force. One possible explanation for this shift could be the fact that unhedged performatives are not appropriate for those contexts (high imposition) and therefore they decided to soften the illocutionary force of their requests in the subsequent tests. Once again, this indicates a positive development in the learners' pragmatic competence in study abroad context. This finding supports the findings of previous research by Hill (1997) and Schauer (2009) that when learners' pragmatic competence is reinforced, they begin to refrain using unhedged performatives and tend to employ strategies with lower illocutionary force. However, the figured data also represent that the same as previous studies (e.g., House \& Kasper, 1987; Kasper, 1981; Schauer, 2009; Warga, 2004) in general SA learners employed hedged performatives considerably more than native speakers.

Among the direct strategies, only the locution derivables were frequently used by both the learners and native speakers which were used in asking for directions in lower imposition situations (scenarios 2 \& 12). One possible justification for this could be the fact that SA learners had a great deal of practice in asking for directions while living in the second language context. Comparing the learners' use of Locution derivables in the pretest and post-tests, it can be surmised that the SAlearners soon became aware that they can confidently use this kind of direct strategy when asking for directions.

Compared to the three previously discussed direct request strategies, want statements were used infrequently by both the SA group and native speakers in high imposition categories. In this case, similar to the data in Schauer's (2009) study, the elicited data in research also suggest that study abroad context had very meager effect on the learners because no remarkable change is seen among the result yielded by pre-test and post-tests. The results in this research seem to support the findings by House and Kasper (1987) and le Pair (1996) in which want statements were not used frequently than other request strategies by the learners and also native speakers. The same as other direct strategies, want statements were also generally softened by internal and external modifiers in order to lessen the illocutionary force of the request. 
Results demonstrate that suggestory formulas were rarely used by both the learners and native speakers. This finding is supported by the findings by previous studies in which suggestory formulas were not frequently employed in making requests by their learner participants (Blum-Kulka, 1989; Kasanga, 1998; Trosborg, 1995; Warga, 2004). Studies by Achiba (2003) and Ellis (1992) showed a decreasing development in the learners' use of suggestory formula requests. In my data only three students in the learner group and four native speaker participants used this strategy in scenario 6 with high imposition in which the participants asked to postpone meeting each other to the next day, for example, 'I can't come today. Please meet tomorrow at the same time' (SA group) or 'I can't make it. Let's meet tomorrow' (native speaker). However, as few students used this strategy in post-tests and one learner stopped to employ it in post-test 2, this doesn't indicate a development in pragmatic competence in study abroad. Moreover, for one learner, the use of suggestory formula was evaluated as an inappropriate answer because the evaluator commented that the participant's answer was problematic in the level of politeness.

Temporal availability as the second indirect strategy was employed by a number of learners in this study. Although compared to other indirect strategies like prediction, permission, willingness, and ability, it was employed less, it was used more than suggestory formulas and direct strategies except locution derivables. However, the results obtained from learners' pre-test and posttests show an increase in the number of employed temporal availability strategies toward being native-like although they slightly exceeded the native speakers in post-test 2 . This is maybe because of the feeling of confidence that the learners acquired through interaction with native speakers that, this strategy when used with softeners are safe to use. Dissimilar to Warga (2004) and Schauer (2009), the learners in this study show pragmatic development to some extent as they made their use of this strategy matched to the native speakers' performance.

The results on prediction reveal that this strategy was mostly used in high imposition situations with equal and higher status by both learners and native speakers. As figure 3 shows, almost all SA learners used this strategy in post-test 2. The learners' performance on pre-test, post-test 1 , and post-test 2 shows a steady increase in employing the number of permission strategy requests. Therefore, based on this approximation in performance between learners and native speakers, it can be concluded that study abroad definitely had a positive impact on students' pragmatic development in the $\mathrm{L} 2$ context.

Concerning permission, a simple look at figure 3 clearly demonstrates that SA learners' performance developed toward being native like. This strategy was used by both the SA learners and native speakers in all four categories of high and low imposition in equal and higher status. As it can be seen, the learners attempted to approximate their performance to the native speakers'. However, the data show that learners used this strategy less than native speakers. This finding is supported by Schauer's (2009), Hill's (1997), and Warga's (2004) findings in which their participants used the permission strategy less than native speakers. Schauer mentioned that the reason for this can be the fact that permission strategy is the only speaker oriented strategy among conventionally indirect strategies. In other words, the focus of the request utterance in permission is on the speaker. One possible explanation for this can be that, because in Persian language hearer oriented strategies are more favorable, the learners preferred to employ this strategy to make their request work fruitfully. Shcauer also claims that with the exception of hedged performatives, the learners' frequent preference in the employment of hearer-oriented strategies such as ability, willingness, and prediction can be because of the fact that learners prefer to employ non-speaker oriented strategies because of their lower illocutionary force nature.

Regarding willingness, the results in this study show that among the strategies discussed so far, willingness has been widely used both by the SA learners (93\%) and native speaker group (90\%). This reflects the popularity of this strategy among English language speakers. In the first data collection, some learners used this strategy, but the number of students using this strategy increased in post-test 1 and 2. Dissimilar to Schauer's (2009) study in which he concluded that study abroad may not have any effect on the learners' employment of this strategy, the results in this study indicate that the learners learned to use this strategy through studying abroad which can be considered as the positive impact of studying abroad on pragmatic development in request speech act. As a matter of fact, the learners and native speakers simply used a few fixed willingness request formulas such as 'Would you please ...', 'Would you be so kind as to ...', or Would you mind ...' '. This popularity in the use of this strategy shows that it can be appropriate in both equal and higher status of low and high imposition.

The last but not the least, is the ability strategy. Interestingly, all the $72 \mathrm{SA}$ participants in all three tests and all the 60 native speakers used this strategy. This result is in line with findings by (e.g., House \& Kasper,1987; le Pair, 1996; Otcu \& Zeyrek, 2008; Schauer, 2009; Warga, 2004; Wodfield, 2008) whose participants also employed ability as the major request strategy and it is in disagreement with Hill's (1997) whose learners mostly used willingness in their request utterances. The same as willingness, this amount of employing ability strategy demonstrates that both native speakers and learners regarded this strategy to be appropriate in both equal and higher status with low and high imposition situations. The frequent use of this strategy by both the learner group and native speakers indicates that using this strategy is safe in most cases. Another interesting result is this research was that learners' use of ability strategy decreased in post-tests because through getting more proficient learners they preferred to use other conventionally indirect strategies which need more proficiency in pragmatics. This means that the learners felt pragmatically confident enough to dare to employ more advanced forms of request utterances. 
Results with regard to non-conventionally indirect strategy hint reveal that participants in both SA and native speaker groups used this strategy in low imposition situations in which the speaker puts a low imposition on the hearer. This finding supports the previous findings by Blum-Kulka and House (1989), Weizman (1989, 1993), and Schauer (2009) in which their participants used hints in situations with a low imposition degree. As a matter of fact, in situations with a higher imposition degree both the learner and native speaker groups employed hints with internal and external modifiers like grounders which provide an explanation for the request (e.g., Erm, unfortunately, I really don't understand this topic here), disarmers which are used to pre-empt the interlocutor's potential objection (e.g., I know you are really busy, but maybe you got some minutes for me), and sweeteners which are used to put the hearer into a positive mood (e.g., I think you are the perfect person to do it), etc. to make the hints strategy more polite.

Regarding the frequency in employing the non-conventionally indirect hint strategy, the results show that although the learners' use of this strategy increased steadily in subsequent post-tests which can be interpreted as a positive impact of study abroad, the SA participants employed this strategy far less than native speakers. This result is also supported by findings in Schauer's (2009) study in which the native speakers employed hints much more than learners. According to Schauer, one possible explanation for this result could be that "the learners may be unsure about their ability to encode their intent in the L2 in a way that will be inferable by a member of a different speech community and culture" (p. 160). However, that fact that study abroad context has a pay-off in learners' employment of hints is undeniable.

\section{Conclusion}

The elicited data in this study revealed that the number of strategies used by the SA learners increased subsequently in post-test 1 (after three months) and post-test 2 (after six months). This increase in each post-test is considered as the positive impact of study abroad duration on pragmatic competence development. Moreover, the result indicated clearly that conventionally indirect request strategies were remarkably employed by both learner and native speaker groups. This shows that learners soon found out that this category is the safest strategy to use in request utterances.

A comparison of the SA learners and native speakers' employment of individual strategies show that ability as a conventionally indirect strategy was used by all the participants in the study. This strategy was the only one that all the learners used in pre-test, post-test 1 and post-test 2 . This demonstrates the popularity and universality of this strategy in both second language learners and native speakers. This finding supports the previous findings regarding request strategies (e.g., House \& Kasper, 1987; Otecu \& zeyrek, 2008; Schauer, 2009; Woodfield, 2008) in which the ability strategy was used frequently as a standardized way to formulate request utterances.

The data also revealed that among the direct category strategies, locution derivable was employed more than other direct strategies which were mostly used for asking for directions. On the other hand, among the conventional indirect strategies, suggestory formulas were used infrequently both by learners and native speakers. For this strategy the impact of L2 context was so meager to be considered as beneficial. Other conventionally indirect request strategies namely availability, prediction, permission, willingness, and ability were used frequently by both the learners and native speakers. Among them ability strategy was employed the highest in pre-test and posttests (pre, $31 \%$, post 1, 28\%, post $2,26 \%$ ). In most of the strategies in conventionally indirect category, the positive effect of length of stay in study abroad context was proved. The learners' use of request strategies in pre-test, post-test 1 and post-test 2 represents an increase in the strategies which the native speakers preferred to use in those situations. Especially regarding the use of ability strategy, at the end of their stay in the study abroad context, the learners' employment of ability was similar to the native speakers'. In other words, considering the conventionally indirect request strategies, the length of stay helped the learners to become more native like in using request strategies.

The analysis of non-conventionally indirect hints confirms that learners used this strategy much less than native speakers. One explanation for this could be that, to be on the safe side, learners prefer to use strategies that are more straightforward in meaning in order to avoid misunderstanding and explanations. This study also revealed that learners and native speakers used internal and external modifiers to soften their direct and conventionally indirect requests.

All said, it can be claimed that the study abroad in general and length of stay in particular are influential in developing the L2 learners' pragmatic competence. In other words, length of stay in study abroad context improves learners' use of request strategies.

\section{Acknowledgment}

This article is a report from the author's PhD dissertation under the guidance of Dr. R. Subbakrishna, professor-cumdeputy director at the Central Institute of Indian Languages (CIIL), Mysore, India. I would like to take this opportunity to express my deep sense of gratitude to my guide for his enduring inspiration, guidance, thought provoking suggestions, wholehearted support and all his monumental patience, nobility and kindness which enabled me to pass through successfully a good number of necessary ordeals. My special thanks are to the native speaker teachers Mrs. Nila and Mrs. Samantha for their great kindness in evaluating and scoring the questionnaires.

The last but not the least, I also owe my special thanks to all the respondents including the SA learners and native speakers for filling the questionnaire with an immense level of spirit.

\section{References}


Achiba, M. (2003). Learning to request in a second language. Clevedon: Multilingual Matters.

Blum-Kulka, S. (1989). Playing it safe: The role of conventionality in indirectness. In S. Blum-Kulka, J.

House \& G. Kasper (Eds.), Cross-cultural pragmatics: Requests and apologies (pp. 37-70). Norwood: Ablex Publishing.

Blum-Kulka, S., House, J., \& Kasper, G. (1989a). Investigating cross-cultural pragmatics: An introductory overview. In S. Blum-Kulka, J. House \& G. Kasper (Eds.), Cross-cultural pragmatics: Requests and apologies (pp. 1-36). Norwood: Ablex Publishing Corporation.

Blum-Kulka, S., House, J., \& Kasper, G. (Eds.). (1989b). Cross-cultural pragmatics: Requests and Apologies. Norwood, NJ: Ablex

Bublitz, W. (2001). Englische Pragmatik: Eine Einführung [English pragmatics: An introduction]. Berlin: Erich Schmidt Verlag.

Ellis, R. (1992). Learning to communicate in the classroom: A study of two language learners' requests. Studies in Second Language Acquisition, 14(1), 1-23. Ellis, R. (1994). The study of second language acquisition. Oxford: Oxford University Press.

Golato, A., Golato, P. (2013). Speech Acts. In A. C. Chapelle (Ed.). The encyclopedia of applied linguistics. (Vol, 9) London, England: Willey-Blackwell.

Hill, T. (1997). The development of pragmatic competence in an EFL context (Unpublished doctoral dissertation). Temple University, Tokyo.

House, J., \& Kasper, G. (1987). Interlanguage pragmatics: Requesting in a foreign language. In W. Lörscher \& R. Schulze (Eds.), Perspectives on language in performance (Vol. 2, pp. 1250-1288). Tübingen: Narr.

Kasanga, L. A. (1998). Requests in English by second language users. ITL, Review of Applied Linguistics, 119$120,123-153$.

Labov, W., \& Fanshel, D. (1977). Therapeutic discourse: Psychotherapy as conversation (pp. 84-85). New York: Academic Press.

le Pair, R. (1996). Spanish request strategies: A cross-cultural analysis from an intercultural perspective. Language Sciences, 18(3-4), 651-670.

Otcu, B., \& Zeyrek, D. (2008). Development of requests: A study on Turkish learners of English. In M. Puetz \& J. Neff van Aertselaer (Eds.), Developing contrastive pragmatics: Interlanguage and crosscultural perspectives (pp. 265-300). Berlin: Mouton de Gruyter.

Trosborg, A. (1995). Interlanguage pragmatics. Berlin: Mouton de Gruyter.

Van Mulken, M. (1996). Politeness markers in French and Dutch requests. Language Sciences, 18(3-4), 689-702.

Warga, M. (2004). Pragmatische Entwicklung in der Fremdsprache. Der Sprechakt 'Aufforderung' im Französischen [Pragmatic development in the foreign language. The speech act 'request' in French.] Tübingen: Gunter Narr Verlag.

Weizman, E. (1989). Requestive hints. In S. Blum-Kulka, J. House \& G. Kasper (Eds.), Cross-Cultural pragmatics: Requests and apologies (pp. 71-95). Norwood: Ablex.

Weizman, E. (1993). Interlanguage requestive hints. In G. Kasper \& S. Blum- Kulka (Eds.), Interlanguage pragmatics (pp. 123-137). Oxford: Oxford University Press.

Woodfield, H. (2008). Interlanguage requests: A contrastive study. In M. Puetz \& J. Neff van Aertselaer (Eds.), Developing contrastive pragmatics: Interlanguage and cross-cultural perspectives (pp. 231-264). Berlin: Mouton de Gruyter. 


\section{Appendix A:}

The Discourse Completion Task (DCT) on request utterances.

Developed by Schauer (2009)

Name: Age: Gender: M D Date:

Length of stay in an English speaking country:

Travel experience to an English speaking country:

If Yes, how long did you stay altogether:

Please read the following description of situations and then write what you would say in each situation. Write your answers in You say: section. An example is provided

\section{Written instructions}

\section{Sample scenario}

Thank you very much for participating in my research. In the following you will see 16 scenarios and a sample scenario. Each scenario is introduced by a picture along with a short description of the situation. Please look at the picture and read the description about the situation carefully and in the part 'You say:' write what you would say in each situation. You can choose a name for the persons in the picture and your answer if you like.

\section{Sample scenario}

\section{A) Asking a friend for the time}

You are having coffee with a friend before your seminar. You want to check whether you have to leave soon, when you realize that you don't have your watch with you. You ask your friend for the time.

You say: Excuse me! What time is it, please?

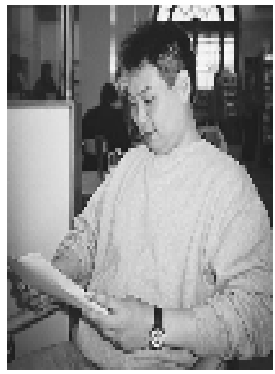

\section{Scenario 1}

\section{(1) Asking a professor to open a window}

You are attending a seminar. It is a very sunny day and the classroom is hot. The professor is standing near the window. You ask him to open it.

You say:

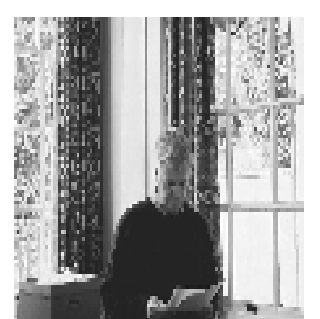

\section{Scenario2}

\section{(2) Asking a professor for directions to the Trent Building}

You are in the corridor of your department. Your next seminar is taking place in the Trent Building, but you don't know where the Trent Building is. One of your professors, Professor Jones, is walking down the corridor towards you. You ask him for directions to the Trent Building.

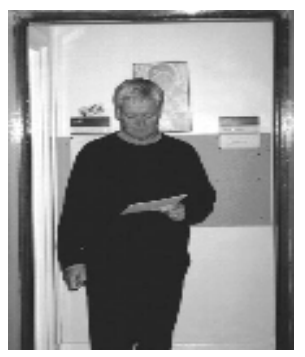




\section{Scenario 3}

\section{(3) Asking a friend to fill in a questionnaire}

You have to ask a student to complete a questionnaire for one of your projects. You decide to ask Lucy, a friend of yours. You know that she is very busy with her own projects at the moment, but you feel that she is the best person for your assignment. At the end of the seminar, you turn to her and ask her to complete the questionnaire for you.

You say:

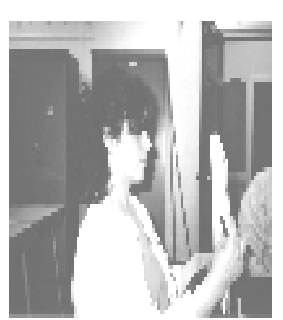

\section{Scenario 4}

\section{(4) Asking a professor to select and bring in articles}

You are having difficulties finding articles and books for one of your essays. You hardly found anything in the library and fear that you will not be able to write the essay. Your professor, who gave you the essay topic and who is a specialist in this area, is conducting a seminar. After the seminar is over, you go up to her and ask her to bring in some articles for you. You also tell her that it is urgent.

You say:

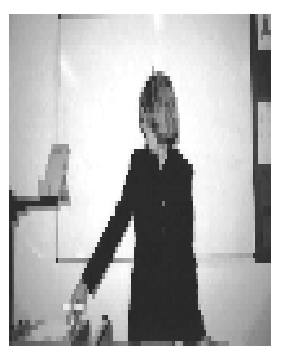

\section{Scenario 5}

\section{(5) Asking two professors to step aside}

You have to hand in an essay to the secretary. The secretary's office is closing soon and you are already running late. When you get to her office, two professors are standing in front of it. You ask them to let you through.

You say:

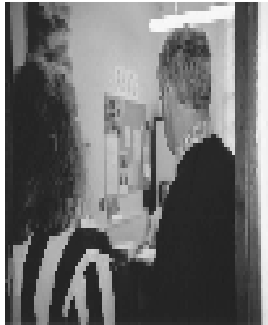

\section{Scenario 6}

(6) Asking a friend to meet you on another day

You arranged to meet a friend of yours at 4 p.m. to help you with your essay. However, on the morning of your meeting, you wake up with a terrible toothache and the dentist can only see you at 4 p.m. Your friend has cancelled another meeting to see you this afternoon and is very busy, because he has to hand in his essays soon. You wait for him after his seminar and ask him to meet you tomorrow instead.

You say:

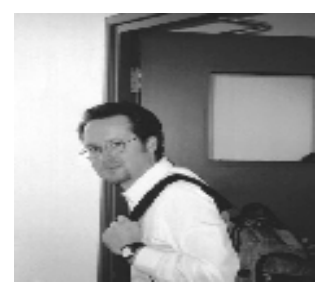

\section{Scenario 7}

\section{(7) Asking a friend to speak louder}

You and some of your friends are having a snack in the cafeteria. One of your friends is telling you something about new university regulations for your course. But you cannot hear her very well, as it is quite noisy. You ask her to speak louder.

You say:

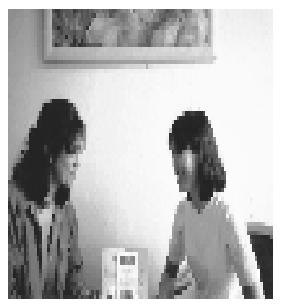




\section{Scenario 8}

\section{(8) Asking a professor for a meeting during the holidays}

You are in your professor's office. It is the last day before the university holidays. You are staying in Nottingham during the holidays to finish your essays. You are having difficulties with your topic and fear that you will need some more help. You ask your professor for a meeting during the holidays.

You say:

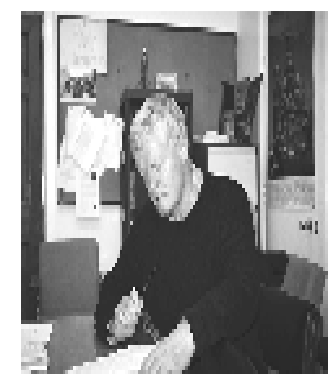

\section{Scenario 9}

\section{(9) Asking a friend to open a window}

You are attending a seminar. The sun is shining into the classroom and it is very hot. A friend of yours is sitting next to the window. You turn to your friend and ask him to open it.

You say:

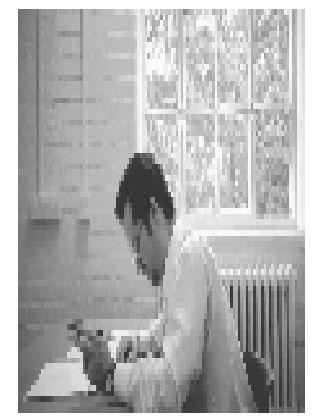

\section{Scenario 10}

\section{(10) Asking a friend to lend you books and bring them in}

You are having difficulties finding articles and books for one of your essays. You hardly found anything in the library and fear that you will not be able to write the essay. A friend of yours is in the middle of writing an essay on a similar topic and has bought several books on this topic. The library does not have these books. You and your friend are standing in the corridor of your department. You turn to her and ask her to lend you the books and bring them in for you the next day.

You say:

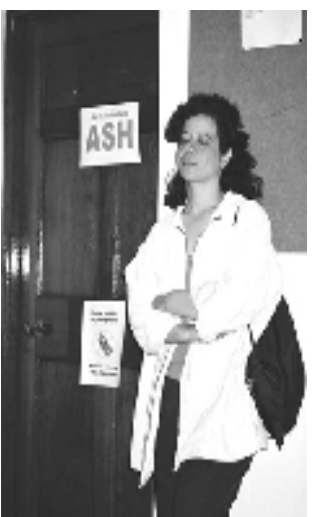

\section{Scenario 11}

\section{(11) Asking a professor to complete a questionnaire}

You are running a project for which you would like your professor to complete a lengthy questionnaire. She is a very busy person, but the questionnaire is essential for your project. At the end of class, you go up to the professor's desk and ask her to complete the questionnaire for you.

You say:

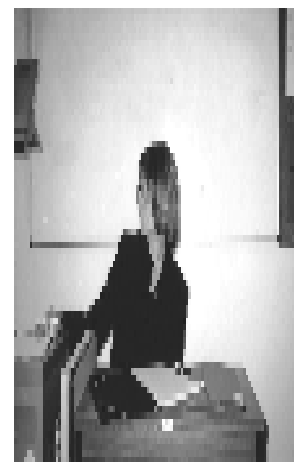




\section{(12) Asking a friend for directions to the Portland Building}

You are standing in front of the library. Your next seminar is taking place in the Portland Building, but you don't know where the Portland Building is. A friend of yours is walking towards you. You ask him for directions to the Portland Building.

You say:

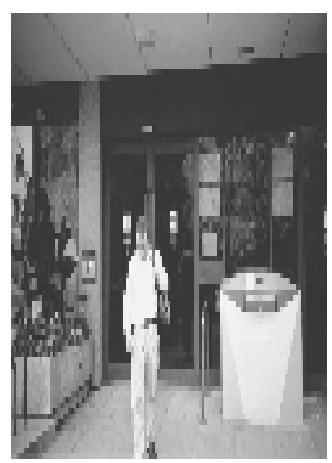

\section{Scenario 13}

\section{(13) Asking a professor to meet you on another day}

You arranged a meeting with a visiting professor, who is always very busy. On the morning of the meeting you wake up with a fever and a terrible cold. You attend his seminar, but feel too ill to meet him afterwards. You go to him during a short break and ask him for another appointment.

You say:

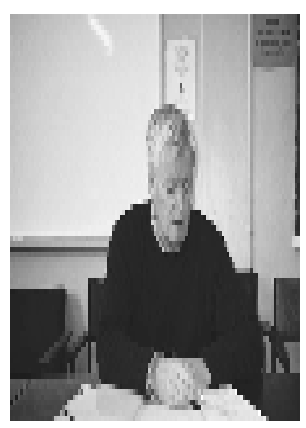

\section{Scenario 14}

\section{(14) Asking friends to step aside}

You have an appointment with a professor. When you arrive at her door, two of your friends are looking at her timetable and are blocking the door. You ask them to move aside.

You say:

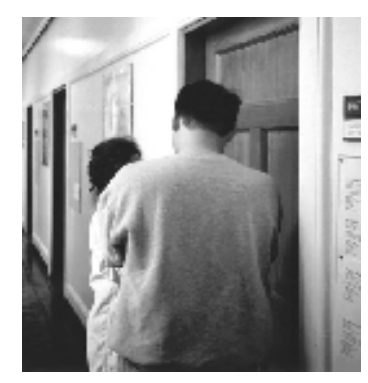

\section{Scenario 15}

\section{(15) Asking a friend to meet you and explain a concept}

It is the last day before the university holidays. You are staying in Nottingham during the holidays to prepare for your exams, but you are having difficulties with one of the concepts that is essential for the exams. Your friend understands the concept, but is flying home in two days and is quite busy. You turn to him after the seminar is over and ask him to meet you and explain the concept to you.

\section{You say:}

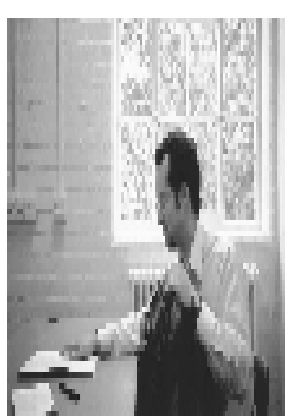


Scenario 16

(16) Asking a professor to speak louder

You are attending a seminar. The professor is explaining a new concept, but you cannot hear her very well. You ask her to speak louder.

You say:

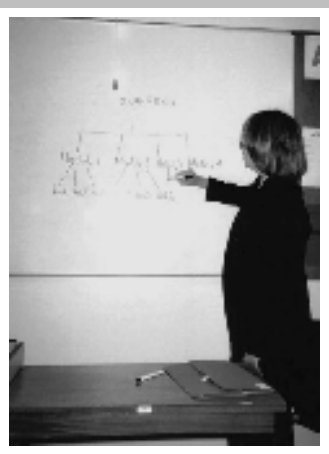

